\title{
The Determinants of Financial Performance of SACCOs in RWANDA: The Case of Gakenke District
}

\author{
SIBOMANA Silas (MBA Student), Elijah Maringa (Lecturer Finance) \\ Department of Finance, University of Kigali, Rwanda
}

\begin{abstract}
This study examined different determinants of financial performance of SACCOs in Gakenke District in Rwanda. The study had an objective of to make an evaluation on whether determinants affect financial performance of SACCOs in Gakenke District. The hypothesis to be tested was that how different determinants affect financial performance of SACCOs. A sample of 63 employees out of 76 managers, accountants, loan officers and chairmen of BoD in SACCOs located in Gakenke District was considered .Simple random selection was considered based on purposive sampling technique. The study was both qualitative and quantitative in nature. Interviews, questionnaires and observations have been used to collect the required data. The collected data was presented using tables and pie charts. The findings were based on objectives of the study .The findings indicated that the majority of respondents agreed that different determinants affect financial performance of SACCOs.It is further revealed that many of SACCOs in Gakenke district do not use advertisement for product differentiation. Also the scope and coverage of SACCOs was limited to the employees in administration level only. The main conclusion was that there was overreliance on debts (deposits) financing when extra funds is needed by majority of SACCOs and SACCOs do not use their reserves to settle debts at maturity.The main recommendations of the study includes that the National Bank of Rwanda must avail enough fund for loan restructuring in order to reduce NPLs and increase the liquidity for SACCOs in order to increase the level of performance of SACCOs. Gakenke district should help the SACCOs in recovering debts and assist SACCOs to persuade borrowers to pay their debts and also depositors to increase their savings for better performance of SACCOs. The management of SACCOS must ensure that there is an adequate and strong credit committee and strong system of recovering of loans in order to increase their performance.
\end{abstract}

Keywords: Financial Performance, Saving and credit co-operative, Return on Equity, Return on Investment. Return on Asset.

DOI: $10.7176 /$ RJFA/12-18-10

Publication date:September $30^{\text {th }} 2021$

\section{INTRODUCTION}

Savings and Credit Co-operatives first appeared in Germany in the 1870's. The idea moved to North America in 1900 with European immigration. Canada, the United States, Australia and Ireland had the most established movements. In many regions of these countries SACCOs are much larger than the commercial banks.

At this time though the Credit Unions were formed as social organizations and did not operate their cooperatives as businesses. This brought about a whole lot of problems. Because the Credit Unions did not pay good interest on savings but gave out loans very cheaply, members were not interested in saving with the SACCOs, only getting loans from the SACCOs. Without savings and shares the SACCOs were unable to grow. However, because members were enjoying the cheap loans, they did not want to change the way they operated. Without growth, it was inevitable the SACCOs would stagnate (SACCOs.2011).

A second problem that existed in those days was people were scared to take up leadership positions as there existed a state of emergency in the country during this period.

According to RCA, (2012) the government of Rwanda started to think of establishing Umurenge Sacco in 2008; after carrying out a study that showed $52 \%$ of Rwandans had no access to formal financial institutions and keeping the money by traditional means such as digging a hole.

There are indications that the country's financial sector is becoming more resilient to financial shocks, and the number of financial institutions is on the rise: The number of banks has increased by 40\%, from 10 in 2018 to 14 in 2019. The number of MFIs increased from 1253 in 2018 to 491 by December 2019, including Umurenge SACCOs. The number of insurance companies has increased by 45\%, from nine in 2018 to 13 in 2019, and the number of pension providers increased by $37 \%$, from 41 in 2018 to 56 by December 2019. (BNR reports 20192020.p 142-146)

\section{THEORITICAL FRAMEWORK}

Financial performance is a subjective measure of how well a firm can use assets from its primary mode of business and generate revenues. The term is also used as a general measure of a firm's overall financial health over a given period.( Gordon Scott, 2000)

Financial leverage which is also known as leverage or trading on equity, refers to the use of debt to acquire 
additional assets. The use of financial leverage to control a greater amount of assets (by borrowing money) will cause the returns on the owner's cash investment to be amplified. (Harold Averkamp (CPA,MBA,2003)

A nonperforming loan (NPL) is a loan in which the borrower is default and hasn't made any scheduled payments of principal or interest for some time. In banking, commercial loans are considered nonperforming if the borrower is 90 days past due(Grier, 2007).

The capital structure is the particular combination of debt and equity used by a company to finance its overall operations and growth. (Joel Bessis, 1998).

Market structure refers to how different industries are classified and differentiated based on their degree and nature of competition for services and goods. ( CFA Institute Program Level I, economics I, 2008)

\section{Financial Performance Indicators}

According to the National bank of Rwanda, SACCOs should comply with BNR ${ }^{\text {ee }}$ regulation no 02/2009 stating the best practice for microfinance institutions. The table below illustrates some key financial indicators.

Table 2.1: Financial Performance indicator

\begin{tabular}{ll}
\hline Indicator & Standards \\
\hline Delinquency/Total loans & $5 \%$ \\
Total liquid asset/Total deposits & $30 \%$ \\
Total Equity/Total Asset & $15 \%$ \\
Total loans/Total deposit & $70 \%$ \\
Total loans/Total Equity\& Liabilities & $80 \%$ \\
Fixed asset(Net)/Total Equity & $75 \%$ \\
Insider lending/Total Equity & $20 \%$ \\
\hline
\end{tabular}

Source: BNR, (2018)

\section{REVIEW OF EMPIRICAL LITERATURE}

Empirical research was conducted and analyzed using qualitative or quantitative methods. There were many variables that determine the financial performance of SACCOs including; Risk tolerance, Dividend payout, Investment culture, Access to financial information, Performance of top management etc. The variables to be considered in this study was enumerated as; Financial leverage, Non-performing loans, Capital structure and Market structure.

Similarly, financial performance of SACCOs can also be viewed in light of their overall financial performance. Herrmann (2008) says that when analyzing a firm's profitability, the concern is with evaluating a firm's earnings with respect to a given level of sales / assets / owners' investment or share value. In doing so, the common profitability measures include: Common size income statements; Return on total assets (ROA); Return on equity (ROE); Earnings per share (EPS); Price/Earning (P/E) ratio Under the common-size income statement, we express every item on the income statement as a percentage of sales, which is gross margin; operating margin; and profit margin.

\section{SACCOs 'Loans and Financial Performance}

A loan is a debt. Like all debt instruments, a loan entails the redistribution of financial assets over time, between the lender and the borrower. The borrower initially receives an amount of money from the lender, which he pays back, but sometimes not always in regular installments, to the lender. This service is generally provided at a cost, known as interest on the debt. The lender may subject the borrower to certain restrictions known as loan covenants. One of the principal duties of financial institutions is to provide loans, this is typically the source of income to SACCOs (Grier, 2007)

\section{Credit Risks in Financial Institutions}

SACCO loan is a debt, which entails the redistribution of the financial assets between the lender and the borrower. The SACCO loan is commonly referred to the borrower who got an amount of money from the lender, and need to pay back, known as the principal. In addition, the SACCOs normally charge a fee from the borrower, which is the interest on the debt. The risk associated with loans is credit risk. (Lynnette, 2008) Credit risk is perhaps the most significant of all risks in terms of size of potential losses. Credit risk can be divided into three risks: default risk, exposure risk and recovery risk.(Gorter \&Bloem, 2001)

\section{METHODOLOGY}

The nature of this research demands the use of quantitative research design. The population of this study encompasses all SACCOs in Gakenke District, a sample of 63 employees in these SACCOs were purposively selected for this study. Data were extracted from audited annual reports and accounts of listed SACCOS in Gakenke District which spanned between 2018 and 2019. The sampling frame for this study included all 
the licensed SACCOs that are in existence within Gakenke by January 2019 and included in the BNR and Gakenke District 's annual supervisory reports for years 2018 and 2019. The list of these SACCOs was extracted from the BNR's list of Microfinance Institutions in RWANDA by the end of year 2019, and verified using the BNR and Gakenke District's annual supervisory reports.

The research needed both primary and secondary data. The primary data was obtained using questionnaire, interview and field visit observation from the employees of SACCO. Secondary data was sourced from historical archives, annual reports, monitoring and planning documents.

Having determined the sample size, there was a need to collect the required data. The methods used in data collection include questionnaires, field observation and interview.

Triangulation data collection was used to as qualitative techniques to get primary data for the research . It comprises three angles: Survey questionnaire, interview and field observation.

Data was analyzed through the use of simple statistical procedures. Statistical tables and simple pie charts was applied to indicate the frequency of responses to particular questions. Moser and Kalton (1971), assert that after data has been edited and coded; it is then combined together in some form of tables, bar graphs and pie charts for statistical analysis.

\section{RESEARCH RESULTS AND DISCUSSION}

\subsection{DESCRIPTIVE STATISTICS}

The results shows that the majority of respondents strongly agree that there is use of debts( deposits of share members) to increase their liquidity at the level of $78 \%, 14 \%$ normally agree, $8 \%$ of the respondents were neutral, while there was no respondents for Disagree and strongly disagree.

According to Pearson correlation where it states that strength and direction of association equal to 0.934 and it is above 0.9 .This means that it is a very positive strong correlation or very high correlation between the use of debts and financial performance of SACCOs.

Also the results shows that the majority of respondents strongly disagree that that financial leverage does not determine the market value of SACCO at the level of $55 \%, 11 \%$ normally disagree, $5 \%$ were neutral ,13\% of the respondents agree with the statements, while $16 \%$ respondents strongly agree that financial leverage determines the market value of SACCO.

According to Pearson correlation where it states that strength and direction of association equal to 0.374 and it is under 0.5 .This means that it is a very low correlation or weak correlation between financial leverage on markets value and financial performance of SACCOs

Further correlation analysis was conducted on various indicators of explanatory variables (Determinants of financial performance of SACCOs) and the response variables ( Financial performance of SACCOs).This correlation analysis aimed at identifying the strongest indicators of the financial performance. The study used descriptive explanatory research design with a longitudinal dimension. As such correlation and regression analysis were considered to explain the interaction between financial performance and its determinants in the SACCOs of Gakenke District. To achieve this , multiple regression line models were obtained for the year 2018 -2019. The software for analysis were Statistical Package for Society Scientists (SPSS) and Microsoft Excel Analysis.

\subsection{DISCUSSION OF KEY FINDINGS}

The findings helped us to describe the variables, evaluation of the relationship between variables and testing the significance of the research hypothesis.

\section{Research hypothesis One:}

H1.The level of financial leverage has significant effect on financial performance of SACCOs in Gakenke District, Rwanda

The study findings indicated that there is over reliance on debt financing and the majority of the respondents agree that SACCO uses its reserves to pay interest and debt at maturity. However it must noted that use of debt always lead to the increase of cash flow for the SACCO.The findings also indicated that in SACCO, no reserves used to settle debts. And results of findings were against $\mathrm{H} 0$ which was that :

H0: The level of financial leverage has no significant effect on financial performance of SACCOs in Gakenke District, Rwanda.

\section{Research hypothesis Two:}

H2: The non-performing loans have a significant effect on financial performance of SACCOs in Gakenke District, Rwanda.

According to the research and findings, the researcher found that the majority of respondents agree that NPLs had a significant effect on financial performance of SACCO. Majority of the respondents agree that a good 
lending policy may reduce NPLs and a permanent contact between SACCOs and their customers lead to better performance and most of them disagree with credit committee on performance of SACCOs and loan default .

\section{Research hypothesis Three:}

H3: The capital structure has a significant effect on financial performance of SACCOs in Gakenke District, Rwanda.

The study revealed that SACCO's capital structure play an important role in its financial performance through the low cost of finance, use of funds for intended projects and maintaining minimum capital requirements and the majority of them agreed that managers were not subjective to the decisions of capital structure and investment in SACCO where there is a participative and democratic means of decisions.

\section{Research hypothesis Four:}

H4. Market structure has a significant effect on financial performance of SACCOs in Gakenke District, Rwanda.

Results indicated that there were effective policies well designed that guides operations in SACCOs in relation to the competition of other MFIs. The study indicated that there is a strong relationship between market structure and financial performance whether in SACCO, the majority agreed that there was a market research before designing a product even if advertisement was not given priority.

\subsection{SUMMARY OF REGRESSION ANALYSIS}

Multiple regression analysis aims to examine the effect of independent variables on dependent variables using SPSS Version 20. Table 1 shows the research results.

a. Dependent Variable: Attitudes of respondents towards financial performance /continuity of profit

Model Summary

\begin{tabular}{|l|r|r|r|r|}
\hline Model & \multicolumn{1}{|c|}{$\mathrm{R}$} & R Square & $\begin{array}{c}\text { Adjusted R } \\
\text { Square }\end{array}$ & Std. Error of the Estimate \\
\hline 1 & $.959^{\mathrm{a}}$ & .919 & .918 & .19972 \\
\hline
\end{tabular}

a. Predictors: (Constant), Attitudes of respondents towards determinants of financial performance.

From the results of analysis, the findings show that the independent variables have impact of $91 \%$ of the variation in the level of financial performance of SACCOs as explained by adjusted $\mathrm{R}^{2}$ of 0.918 which shows that the model is a good prediction.

\section{CONCLUSIONS AND SUGGESTIONS}

Based on the research results, the conclusions can stated below.

The aim of this study was to investigate and determine the effects of determinants of financial performance SACCOs in Gakenke district. It was found by the findings that there was over reliance on debts (deposits) financing when extra funds is needed by majority of SACCOs and SACCOs do not use their reserves to settle debts at maturity .

The study also revealed there is no adequate system for credit management which lead to the increase of NPLs that significantly affect negatively on the financial performance of SACCOs. Another findings was that managers rarely pursue their own objectives rather than the objectives of SACCOs. On the market structure as determinant of financial performance of SACCOs, the study found that market research and development is usual an integral part of SACCOs ' operation. However, it was found that advertising of SACCOs' product differentiation is not given priority and this will reduce awareness of level on the products offered by SACCOs as well as varieties and their benefits

Based on the research results, suggestions can be stated below.

The National Bank of Rwanda must avail enough fund for loan restructuring in order to reduce NPLs and increase the liquidity for SACCOs in order to increase the level of performance of SACCOs. The National Bank also should avail the automation system in order to facilitate quick decision for management and timely reporting. This will also facilitate advertising in SACCOs.

Gakenke district should help the SACCOs in recovering debts and assist SACCOs to persuade borrowers to pay their debts and also depositors to increase their savings for better performance of SACCOs. The district also must set a regular campaign to persuade people to join SACCOs and make savings and settle their debts as they fall due.

The management of SACCOS must ensure that there is an adequate and strong credit committee and strong system of recovering of loans in order to increase their performance. SACCOs ' managers must develop a strong 
system and operational strategies that minimize over reliance on debts to safeguard their equity.

It is recommended that SACCOs should establish a strong system of documentation that will minimize defaults loans by customers.

Another recommendation is that SACCOs must make Union and federation with others in order to strength their level of capital structure that will effectively reduce the reliance on debts as a source of funds.

It is recommended that the SACCOs keep regular activities related to market research and development and they prioritize advertising for product differentiation.

Future study should also focus on comparative analysis on financial performance with other related companies in the same industry such as commercial banks (B.K, BPR, ) and insurance companies (SAHAM.SANLAM...).The study must be also conducted basing on the year 2020 of COVID-19 in order to assess the performance of SACCOs during this pandemic.

Research can also be carried out on efficiency and effectiveness of internal control system of SACCOs to ensure that all expenses are incurred effectively and efficiently in the performance of SACCOs.

Further research should be carried out on risks management and performance of SACCOs and capital management and performance of SACCOs in Rwanda.

\section{REFERENCES/ BIBLIOGRAPHY}

Adera, A. (1995). "Instituting effective linkages between formal and informal financial sector in Africa: A proposal" Savings and Development, Vol. 6: pp 5-22. Accessed: 10/052013

Annan, K. (2004), Microcredit extends same rights to the poor as are available to everyone else, says SecretaryGeneral Message to launch for international year, retrieved from http:/www.un.org/NewsPress

Anupam, A. (2004). Micro finance in Africa: Experience and lessons from selected African Countries, International Monetary Fund.

Burgess, R., Wong, G.\& Pande, R. (2005). Banking for the poor: Evidence from India. Journal of the European Association, Vol. 3, No. 2/3, papers and proceedings of the Nineteenth Annual Congress of the European Economic Association (Apr. -May, 2005), pp.268-278. Accessed 07/06/2012

Carilus ,A. (2012), Challenges Facing SACCOs in Africa today; Executive Director ACCOSCA. Accessed on 20/06/2013

Consultative Group to Assist the Poor \& the World Bank Group. (2010). Financial Access 2010: The State Financial Inclusion through the Crisis. Retrieved from CGAP website: http:/www.cgap.org

FinScope (2012). Financial inclusion in Rwanda 2008-2012. Access to Finance Rwanda. Kigali, Rwanda

Gilbert, O. (2012), the role of financial services cooperatives (FSCs/SACCOS) in savings mobilization and economic development, University of Zululand. Vol. 12, Number 2, fall 2012. Pp 169-195.

Ministry of Finance and Economic Planning (2009), Umurenge SACCO strategy, Financial Sector Development Secretariat, Government of Rwanda

Mukuye, R. (2004). Micro credit as a tool for Women's Empowerment and Poverty Alleviation in Uganda, international institute of social studies Erasmus University Rotterdam. Accessed on 24/06/2013

Peace, K. (2011). Small savings and credit schemes and financial accessibility in rural areas (4th ed).

Rwanda Cooperative Agency, (2012), Access to Finance in rural area, retrieved from http://www.rca.gov.rw/

Wamba, L.N. (2004). Private Equity \& Corporate Finance in Africa, Johannesburg South Africa. Accessed on $03 / 07 / 2013$ 